\title{
Equivalence in Humour Superiority and Incongruity Translation: A Case of Three Men in a Boat and Three Men on the Bummel
}

\author{
Irina Pușnei Sîrbu \\ Letters Faculty, University in Galati, Romania
}

Copyright $\mathrm{C} 2016$ by authors, all rights reserved. Authors agree that this article remains permanently open access under the terms of the Creative Commons Attribution License 4.0 International License

\begin{abstract}
In numerous attempts to describe the phenomenon of humour, diverse theories have been proposed: ones, revealing its superiority that evolves from aggression, derision, mockery, malice, and abuse; others, focusing on the humorous incongruity contrastive and confusing effects. As far as the superiority theory is concerned, it commenced with ancient philosophers' works like Aristotle's Poetics [1] and Plato's Republic [2] advancing the hypotheses of the malicious or derisive enjoyment caused by ridiculing and imitating mistakes or deformities, continued with Hobbes' theories of laugher regarding it as a "sudden glory" and triumphant "self-applause" over the misfortunate exposed in Leviatah [3] and developed with controversial statements of superiority being too limited and poor a concept without incongruity. Though most authors agree that it is the frustrated expectation that makes the joke or narrative amusing, we support Vandaele's [4] position concerning both theories being complementary. Since humour is a challenging translation area, rendering comic suspense and surprise without exaggerating the humourist's superiority or diminishing his preeminence turns out to be really difficult an assignment for translators. The research question this study addresses is whether translation equivalence may be achieved when transferring narrative humour linguistic, social, contextual incongruities and positive/negative superiority from source to target text. To answer this question, detailed systematic corpus analysis has been done aiming to systematize and compare target language translated versions of J. K. Jerome's Three Men in a Boat (1889) and Three Men on the Bummel (1990), to identify humour translation difficulties with concern to incongruity translation (non)equivalence and (non)aggressive superiority. Part of this comparative analysis is intended to determine the transferred comic sense quality, to consider its denotative or connotative target language equivalents which are doubtlessly contextually motivated. The present
\end{abstract}

study results give priority to humorous meaning interpretation achieved by means of dynamic equivalence techniques that justify or criticize Romanian translators' competences of decoding so relative, complex and mysterious a phenomenon as humour.

Keywords Comic Surprise, Comic Suspense, Narrative Humour, Dynamic Equivalence, Superiority

\section{Introduction}

The concept of humour has long been studied and the deeper it is investigated, the more relative, multidimensional and puzzling it appears to be. In many attempts to academically corral this phenomenon, several theories have been proposed: Superiority and Incongruity theories being under the major focus of this study.

The earliest reflections on humour strongly associated it with laughter as "a violent emotion" resulting from mockery or comic aggression that might threaten the "control over oneself" [5]. With this primitive regard to humour as a "form of derisive enjoyment", Plato emphasizes its viciousness which is later found in his disciple's work as indicating "a species of the ugly" and a "baseness of the soul" [6]. The Greek philosophers' position on humour laid the basis of the Superiority theory and developed later into Hobbes's theories which criticized laughter as well. Besides reinforcing the ideas of "malice" and "derision" in laughter, Thomas Hobbes (1651) advanced the concept of the humorist's "self glory" which derived from the triumphant "eminence over one's misfortunes" or over "deformed things" and "selfish applaud at one's witnessing accident and acknowledging the power over the ridiculed". Regarding laughter at the 
defects of others as a sign of pusillanimity, Hobbes and his contemporary thinker Descartes [7] highlighted its hostile and scornful nature, although the latter placed it among the other emotions such as wander, love, desire, joy and sadness. Yet, the arguments of this theory were not sufficient to convince the adherent thinkers in its being thoroughly indisputable. Despite acknowledging the fact that "laughter looks down on whatever it laughs at" and that "it involves a winner and a loser", Vandaele [8] found Hobbes's position too narrow to cover every type of humour. Hutcheson (1750) quoted by Sandford Encyclopedia of Philosophy [9] and Alexander Bain [10] were the first to bring their counterarguments concerning the varieties of superiority, its intentionality, necessity and adequacy. Admitting the relativity of superiority on one hand and it's comic effect on the other, the above mentioned critics of the Hobbes theory assert that the humorist may either appear superior or inferior to the audience depending on his purpose which may also be missing (he may not be conscious at his own superiority) and on the object that must not necessarily be a person but an idea, political institution or anything that makes a claim to dignity or respect. What is more, they acknowledge that it is not only superiority that makes humour amusing but the contrast between the exalted or dignified and something trivial or disreputable which Spencer (1860) cited by Monro (1988) [11] calls incongruity. Inconsistent in its nature, incongruity reflects counterapositions of various kinds: conflicting meanings, action and behaviour, reason and emotion, appropriateness and inappropriateness, word and occurrence. Kant (1790), cited by Sandford Encilopedia of Philosophy (2012) [12] regarded incongruity in laughter as "a sudden expectation into nothing" where, as Monro [13] puts it, "nothing" is the unexpected meaning. These reflections, though indirectly, establish the connection between contrasting meanings and resolution. These contrastive elements may be combining possible vs. impossible meanings, appropriate vs. inappropriate words, rational vs. absurd actions and reactions, creating surprising and comic effects which are assembled in Shultz 's view on incongruity quoted by G. Ritchie, (2009) [14]: "the simultaneous presence of two or more habitually incompatible elements, where an element can be either an object or an event".

With general considerations on humour incongruity at the level of actions and events on one hand, and the narrow contrast between what is said (words) and what is expected on the other, indisputable rests the disagreement which must be at least partially solved in order to appreciate humour and make it enjoyable. Therefore, humour incongruity tests the recipient's ability to cognitively unveil the deliberately created contrasting "lines of thought" because any mental fluctuation requires brain activity so indispensable for humour comprehension and appreciation.

\section{Superiority and Incongruity Interaction}

Some studies on Humour (Bergson, Monro, Vandaele) criticize Superiority theory for neglecting incongruity and the Incongruity theory for being "black-box"-like [15]; others (Lippitt, 1993), on the contrary regard them not being "self-contained having the tendency to spill over one another". Isolating both theories is not the aim of this section, it being directed towards establishing a connection between them and to prove that humorous devices implying simultaneously superiority and incongruity may produce the intended or spontaneous humorous effect. Attempts to illustrate the relation between superiority and incongruity are observed in Vandele's [16] research where he introduces the concept of "narrative humour" as integrating both, and further proposes at least 4 specific ways of interweaving both theories: normalization, evaluation through indirect communication, solution and conditioning. To make this outlook on narrative humour reasonable and practical for the present study that focuses on collecting humorous devices from J.K. Jerome's novels Three Men in a Boat and Three Men on the Bummel we shall make an attempt to apply the above listed principles.

As far as the principle of normalization is concerned, it refers to establishing a relation between the two theories in order to reveal the humorous devices that will combine:

a) negative superiority and incongruity: aggression and contrast between what is being said and what is being implied (irony), superiority and two different meanings (pun), derision and conflicting social value and vice (satire), ridicule and norm conflicting or exaggerated actions, descriptions (caricature);

b) positive superiority and incongruity is also possible when we refer to the pleasant reactions it produces: mirth, amusement, exhilaration as well as to "narrative suspense" [17] effect exerted while fusing the humorous feeling, created by the character or narrator, with the tensioned expectation (anecdote). As for the "narrative surprise" [18] effect, it is also emotionally achieved when cognitively determining the contrast between what is expected and what occurs, is insinuated, or what is said (cues, bon mot, jokes, etc.).

Considering the evaluation through indirect communication principle, it is worthwhile to refer to non-verbal expression of superiority and incongruity that may occur in narrative humour by means of situational irony, anecdotes and book events that locate the characters together with the narrator as being superior or inferior one to the other or to the situation they are placed in.

The conditioning principle determines the status of a humorous device being incongruous and displaying superiority in the same time. Taking Vandaele's [19] considerations as a starting point, we shall categorize the humorous devices in the following way:

a) Negative Superiority and Linguistic incongruity reflected in parody, stereotyping, irony when taking the phonetic level, for example imitating somebody's 
pronunciation defects such as stuttering that creates a comic effect once solving the incongruity (real person/parodist, real/exaggerated) and once feeling superior to the derided;

b) Negative Superiority and Pragmatic Incongruity reflected in both verbal and situational irony which is in a strong connection with ambiguity created by the contrastive implication as well as in pun which is intentionally created to puzzle the humour recipient and then to make him feel superior when comprehending the word play or inferior when not;

c) Negative Superiority and Social Incongruity reflected in satire by means of real, exaggerated or even absurd social vice counter positions that produce feelings of superiority on the part of the derider and feelings of inferiority on the part of the derided.

These patterns do not only reveal the fact that both theories can intermingle within different humour devices but also increase the comic effect. Despite prevailing negative superiority component in the above listed combination it is worth specifying that its slightly aggressive and deriding manner makes it attractive. With regard to incongruities, their intentionality is above doubt or dispute irrespective of the types that form the above mentioned combinations.

\section{Equivalence in Humour Translation}

With an emphasis on superiority and incongruity in the context of humour translation, a considerable proportion of the present study is devoted to the examination of different aspects of equivalence aiming to determine whether it is achievable during the translation process. The concept of equivalence implies a semantic proximity of the source and target message (Зангирова, 2010) and is regarded as the main feature and condition of a good translation. Though associated with "identity" which derives from the theory that translation must fully preserve the original content, "usefulness" [20], which implies "a comprehensive transfer of the original semantic content", Translation Studies scholars such as Barhudarov [21] and Leonardi [22] assert that translation equivalence is mostly relative. This happens because the invariant unit of translation is seldom qualified as "equivalent" at more than one level. Likewise, the inevitable loss that occurs during the process, where literary text, different cultures, traditions, mindsets, ages, and development stages are encountered, make the translators' work really challenging. What is more, "absolute" or "total equivalence", as Комиссаров [23] terms it, "is a rather idealized construct" and is almost impossible in literary text translations since complexity, wide range of functional characteristics and different communicative conditions are peculiar to this style of writing. He also emphasizes translator's literary perception, talent and personality which may be reflected in the translated text as well.

Scholars such as E. Nida and C.R.Taber [24] draw the distinction between formal equivalence (structural correspondence) which is contextually motivated and dynamic equivalence which is directed towards the translation of meaning. Catford [25] took a more linguistically-based approach proposing the criteria of extent translation (full vs. partial equivalence), grammatical level (rank-bound vs. unbounded translation); Newmark [26], Baker (1992) [27], House (1997) [28] and Комиссаров (1999) [29] advanced more detailed ways of equivalence classification focusing on communicative, pragmatic, functional, semantic, expression, stylistic, grammatical, textual and syntactic categories. As far as humour translation is concerned, it is worthwhile considering the 5 levels of equivalence advanced by Комиссаров since they contain aspects of dynamic, lexical, pragmatic, and syntactic equivalence which were studied by above mentioned scholars, Equivalence at the level of the aim of communication became the essential criterion in Комиссаров's hierarchy of equivalence levels, which prove the versatility of the concept, and further include: equivalence at the level of situation description, equivalence at the level of expression, equivalence at the level of the meaning of syntactic units, and equivalence at the level of language signs. Thus, equivalence at the level of the aim of communication is built around the idea of conveying the message either directly or indirectly from source to target language. The key point of this level of equivalence is the fact that it highlights the value of the translated meaning which is the core element of dynamic equivalence relevant to such an abstract, relative and complex phenomenon as humour. The equivalence at the situational level not only conveys the aim of communication but also reflects the same extra linguistic situation in terms of objects and the relations between objects described in the statement. This level demonstrates that the communicative function of the text cannot be carried out otherwise than through situationally-oriented messages which may be accompanied with significant structural and semantic differences with the source text. To ensure the situational acceptance by the target language audience, the pragmatic coherence should be considered since it will help meeting the audience's expectations and avoiding their failure in interpreting the conveyed situation. The level of expression encompasses the peculiarities of the previous levels including the preservation in translation of general concepts which contribute to the original situation description. This level of equivalence, which ensures the interpretation of the pragmatic implicature, is achievable by means of semantic paraphrase of the original message into the translated message which reveals the commonality of the basic semantic features. The equivalence at the level of the meaning of syntactic units is achieved by means of reproducing the original meaning of the translated syntactic units. At this level of equivalence 3 types of variation are possible: the use of synonymous structures related by means of direct or back translation, the use of similar structures to change the types of connection between them. The level of language signs is characterized by a high degree of 
parallelism in the structural organization of the text, by the maximal correlation of the lexical structures (compliance with all the significant words of the source is possible), by the preservation of all the main parts of the original content. Besides the peculiarities of the four previous levels of equivalence, here may be added the greatest possible commonality of separate basic semantic features which are component parts of source and target language words.

Given the relative nature of translation equivalence, we are inclined to agree with Виноградов's [30] idea that absolute equivalence is almost impossible in humour translation because it depends on such factors as: translator's skill, SL and TL specific features, the period when the translation was made. Therefore, we will consider Комиссаров's [31] levels of equivalence which combine aspects of Nida and Taber's dynamic equivalence and Baker's pragmatic equivalence as evidence that the translation equivalence of humorous literary texts is mainly relative.

\section{Equivalence in Humour Translation. A Case of "Three Men in a Boat" and "Three Men on the Bummel"}

The bulk of our analysis in the present case study consists of comparing the source and target texts selected from J.K. Jerome's novels Three Men in a Boat and Three Men on the Bummel and sorting them according to the criterion of equivalence adapted to the specific communicative and functional aspects of humour translation which combines some of the Комиссаров's, Nida and Taber's and Baker's elements of translation equivalence classification.

The level of communication purpose implies conveying the humourist's message either directly or indirectly that is intended to inform, to entertain, to amuse, to surprise, to create a comic suspense, to express a positive or negative emotion thus establishing a contact between the humourist and the recipient. Consequently, the corpus material investigated in the present article may be labeled according to the following models of message conveyance:

a) Explicit message conveyance occurs when the intended meaning is directly interpreted from source to target text. In the case of humorous text translations that reflect superiority and incongruity, such devices like anecdote, cue and joke may aim at achieving a humorous effect by means of comic amusement, comic surprise, comic suspense and comic ridicule. Here is an example of interpreting directly these comic effects:

As the object of each student is to go away from the University bearing as many scars as possible, I doubt if any particular pains are taken to guard, even to the small extent such method of fighting can allow. The real victor is he who comes out with the greatest number of wounds; he who then, stitched and patched almost to unrecognition as a human being, can promenade for the next month, the envy of the German youth, the admiration of the German maiden. He who obtains only a few unimportant wounds retires sulky and disappointed. (Three Men on the Bummel, Jerome, 1900: 369)

The present instance of situational humour illustrates how humour superiority and social incongruity may intermingle within satire. Prior to the achieved comic effect several comic elements such as comic surprise and comic ridicule join to directly render the specific of the German Mensur- a traditional kind of fencing practiced among students. Despite the narrator's dry tone that does not betray any sign of direct superiority towards the German student, this is slightly perceptible when deriding the idea of Mensur mutilation being a sign of bravery and triumph. The Geman Mensur, as a specific cultural phenomenon, has designed a certain portrait of the German student which differs from that of any other nationality. This social incongruity creates the comic surprise effect which is intensified by depicting the defeated and the community acknowledgement, envy and admiration towards the Mensur victor.

In order to ascertain the equivalence at the level of message interpretation the following translated versions are proposed:

Cum scopul fiecărui student este să absolve facultatea cu cât mai multe cicatrice, mă îndoiesc foarte că se depune vreun efort serios în apărare, nici măcar în măsura redusă pe care o permite o astfel de metodă de luptă. Adevăratul invingător este cel care recoltează cel mai mare număr de răni; cel care după aceea, insăilat și peticit, încât mai că aproape nu mai arată a făptură omenească, poate $\hat{i} n$ viitoarea lună să evolueze pe promenadă, spre invidia adolescentului german ssi admirația fecioarei germane. Cel care obține numai câteva răni neînsemnate se retrage, botos și dezamăgit. (Trei pe două biciclete, Duțescu, 2009: 379)

Cum scopul fiecărui student este să termine universitatea cu cât mai multe cicatrice, mă îndoiesc că se depun eforturi serioase în apărare, nici măcar în măsura redusă pe care o asemenea metodă de luptă o permite. Adevăratul învingător este acela care adună cel mai mare număr de răni; cel care, după ce este insăilat și peticit, devenind aproape de nerecunoscut, poate să se plimbe în luna următoare pe promenadă, spre invidia tânărului german și admiratia fecioarei germane. Cel care obține doar câteva răni lipsite de importanță se retrage supărat și dezamăgit. (Trei pe două biciclete, Decei, 2006: 261)

Deriving from the idea that to preserve the source text humorous effect while translating it in the target language becomes possible only when the meaning is translated, and the message is correctly conveyed, we shall analyze the 
above translated versions according to the criterion of directly transferring the comic amusement surprise, and ridicule. Given the combination of negative superiority and social incongruity, it is noteworthy that the effect of the ridicule is deliberately created by the author in doubting the pains taken to guard the fighters. The latter is translated like efort serios în apărare and eforturi serioase în apărare where both versions being suspiciously similar are amplified by means of the adjectives serios and serioase, the former taking the singular form by means of transposition. Another sign of comic derision is disclosed in the expression stitched and patched almost to unrecognition as a human being" which, vividly depicts the Mensur victor's appearance, was translated like însăilat şi peticit in both versions, a fact that increases the suspicion on the second version translator being the one who "borrowed" the qualificative. Though Lia Decei's version devenind aproape de nerecunoscut is translated by amplifying the text with the devenind aproape de gerundial phrase, is still closer to the source text rendering directly the description Duțescu's incât mai că aproape nu mai arată a fäptură omenească version, where almost to unrecognition is translated indirectly by adding a subordinate clause having an opposite formulation of the same meaning as the source text and makes the target text look more native-like. The comic surprise effect derives from incongruity which is based on two counter positions: the German Mensur winner vs. typical winner, and Mensur winner vs. Mensur loser. These dichotomy elements reveal cultural differences in describing a student being good looking and admirable by getting many scars in contrast to the common idea of unblemished beauty, the Mensur winner differing from the typical fight winner who usually wins by wounding the combatant, not by purposely obtaining wounds. The first dichotomy element bearing as many scars as possible is directly translated with $\mathrm{cu}$ cât mai multe cicatrice, which despite omitting the gerundial pattern bearing and the as possible structure of equality conveys the original message. Furthermore, the dichotomy element comes out with the greatest number of wounds is directly translated in the target text with care recoltează cel mai mare număr de răni and care adună cel mai mare număr de răni by transferring the meaning of the entire clause and by replacing the source text come out phrase by a recolta/ aduna. The portrait of the loser is also directly transferred in the target text being translated by Dan Duțescu whereas Lia Decei preffered to translate the expression with a few insignificant wounds by paraphrasing it with doar câteva răni lipsite de importantăa preserving the meaning however. Incongruity lays in the comic amusement effect as well, which is created while laughing at the German student who, though enduring terrible pain remains comic, happy and admired. According to the analysis of the above mentioned translation transformations it may be stated that equivalence at the level of communicative aim has been achieved by both translators since they succeeded in explicit message conveyance which denotes the act of derision towards the German student and the German Mensur. The translation of such a culturally specific event as Mensur together with its peculiarities, which are unfamiliar to the Romanian reader, was performed by means of foreignization which stands for the lack of target cultural equivalence. Despite this fact, equivalence at the situational level has been attained due to the extra linguistic situational features conveyance which helps the Romanian reader perceive the derided situational reality. At the level of situational expression, equivalence is achieved when rendering the author's superiority into the target language. Both translators succeeded in reproducing the original meaning of the translated syntactical structures such as the types (predicative, nominative, attributive) and the length of clauses obtaining thus the equivalence at the level of syntactical units meaning with the variation of using similar structures with a change in word order. The hardest achievable is the level of language signs since they are numerous in the present humorous text. Yet, the main parts of the original content have been conveyed by both translation variants with the greatest possible commonality of the source and target basic semantic features.

b) Implicit message conveyance occurs when the intended meaning is indirectly interpreted from source to target text. In the case of humorous texts translations that reflect superiority and incongruity, such devices like irony, caricature, and satire may aim at achieving a humorous effect by means of the same comic elements (amusement, comic surprise, comic suspense and comic ridicule). Here is another example of interpreting indirectly and indirectly these comic effects:

Now, I'm not like that. I can't sit still and watch another man slaving and working. I want to get up and superintend, and walk around with my hands in my pockets, and tell him what to do. It is my energetic nature. I can't help it. (Three Men in a Boat, Jerome: 36)

The irony is a perfect example of implicit message conveyance; what is more, the implied meaning is almost always incongruous with the pretended meaning and shows superiority towards the interlocutor because it is intended to indirectly deride him. While translating ironic texts, the implicature must be directly or indirectly conveyed so that to reshape the humorous effect in the target language. In order to see how it is applicable, we shall analyze the comic effect translated elements proposed by four different translators:

"Eu am cu totul altfel de fire. Nu pot să stau cu brațele încrucișate și să văd cum altul trudește și asudă. Simt întotdeauna nevoia să mă scol și să supraveghez, să umblu după el cu mîinile în buzunare și să-i spun ce are de făcut. De vină e firea mea păcătoasă- sunt prea energic." (Trei într-o barcă, 


\section{Levițchi, 1957(2009):36)}

Ei, dar eu sînt cu totul altfel de om. Eu nu pot sta linistit și să privesc cum muncește cineva. Îmi vine să mă ridic și să dau dispoziții- să mă plimb prin cameră cu mâinile în buzunare și să poruncesc ce trebuie de făcut. Așa-i natura mea -energică. (Trei într-o barcă, Corduneanu, 1959:71)

Dar eu sunt cu totul altă fire. Nu pot sta cu mîinile $\hat{i n}$ solduri să privesc ca un trândav cum cineva muncește $\hat{\imath}$ sudoarea fruntiii. Imediat simt necesitatea de a mă ridica și de a începe să acționez, în timp ce mă plimb incolo și încoace cu mâinile în buzunare și dirijez lucrările. De felul meu sunt foarte activ. Pur și simplu așa sunt eu. Si n-ai ce-i face (Trei într-o barcă, Bătrânu N, 1985(2003):91)

Trebuie să vă spun că eu nu sunt aşa. Nu pot să stau și să mă uit cum altul muncește ca un sclav. Eu simt nevoia să mă ridic și să supraveghez, să mă invârtesc cu mâinile în buzunar și să le spun celorlalți ce au de făcut. Așa sunt eu, un om energic. Nu mă pot schimba.

(Trei într-o barcă, Decei, 2006:53)

The translation of comic irony involves not only transferring the ironist's superiority towards the interlocutor but also his pseudo modesty in self description that only intensifies the effect of pseudo-inferiority and self- derision. The first effect of superiority is revealed in the opening sentence Now, I'm not like that. which was mostly translated indirectly by means of opposite paraphrasing (ei) dar eu sunt (am) cu totul altă fire (de om laltfel de om) that actually preserves the message though replacing the adverb now by the domesticated interjection $e i$, the disjunctive conjunction dar and narrowing the meaning of that by means of specifications fire and fire de om, makes the target text sound more informal than the source. The translator Lia Decei offered a direct message conveyance and almost preserved the original structure excepting the syntactical patterns extension by adding a clause to modify the original one. The second element of superiority occurs with the sentences It is my energetic nature. I can't help it, where the narrator justifies his idleness by revealing his energetic nature and the impossibility to change it. All the translated versions directly convey the message differing just in form. Dan Duțescu added the syntactic pattern De vină e, which was meant to justify the character's energetic nature being translated with firea mea păcătoasă, which conveys the message of it being impossible to change whereas the qualificative energică was compensated in the second part of the sentence. Corduneanu's version is brief. Omitting an entire sentence, he compensates part of its message in the previous one adding the adverb of manner așa and the hyphen that is intended to spare explanatory phrases. Further, Nicolae Bătrînu translates the sentence It's my energetic nature conveying the message indirectly. Moreover, he employs an additional sentence to intensify the message conveyed in the previous one. Replacing the idiomatic phrase I can't help it by its equivalent $n$-ai ce-i face the present translator contributed, in this manner, to direct message conveyance. Syntactically, this translation version underwent transformations in terms of sentence addition and pattern extension. Lia Decei appeals to message content adaptation as well by means of lexical-syntactic restatement Așa sunt eu, un om energic which indirectly conveys the message.

Recreating the implicature in target language text is a challenging translation task as it must contrast with the explicit meaning and create a comic surprise effect. Upgrading the readers' expectations of the narrator being a hard working nature described as I can't sit still and watch another man slaving and working, the intended meaning is suddenly disclosed by the expectation collapse revealed in the sentence I want to get up and superintend, and walk around with my hands in my pockets, and tell him what to do. The expression sit still, for instance was translated by Dan Duțescu like a sta cu brațele incrucișate, by Bătrînu a sta cu miinile in ssolduri by idiomatically translating the meaning and conveying indirectly the message. The translator Decei reduced the source text expression to a sta which was not less sufficient in order to preserve the meaning, whereas Corduneanu employed the expression $a$ sta cuminte which means obedient rather than doing nothing. The second contrastive element which creates the present incongruity does also indirectly convey the intended meaning. All the above mentioned translators preserved this comic surprise effect. Despite the diverse lexical versions of want substitution (simt nevoial simt necesitatea /and the synonymous translation imi vine), and of walk around substitution and expansion să umblu după el/ să mă plimb prin cameră / mă plimb incolo și încoace and equivalent să mă invârtesc, the translators did not distort the message comic effect which is crucial in humour production and appreciation. Considering this example and its translated variants from the viewpoint of translation equivalence levels, it is noteworthy that the level of communicative aim has been achieved by means of implicit message conveyance which leads the Romanian audience to the idea of the narrator's self-irony. The situational level of equivalence was attained by all the Romanian translators' pragmatic coherence in situation reproduction since the reader is placed within the comic reality of the narrator who does nothing but vainly walks around the house instead of working. The pragmatic coherence would not suffice unless the pragmatic equivalence is not achieved by means of implicature conveyance. The equivalence at the expression level is achieved by making the target reader understand that the narrator scornfully alludes at his idleness by means of verbal irony. Not all the translators succeeded in achieving the equivalence at the level of the meaning of syntactical level. Hence, we can observe clause addition in Lia Decei's, Leon Leviţchi's translation variants, clause type changes from direct object to predicative in all the translation variants and sentence juncture in Leon Levițchi's and Corduneanu's variants. The equivalence at 
the level of language signs was achieved by Lia Decei' in her translation variant whereas other translators failed to ensure the compliance with all the significant words partially replacing, omitting or adding words and semantic features to their translation variants.

\section{Research Data}

Table 1. Three Men in a Boat

\begin{tabular}{|c|c|c|c|c|c|}
\hline Humorous devices & Superiority & $\begin{array}{c}\text { Communicative } \\
\text { (pragmatic) }\end{array}$ & Cultural & Linguistic & Situational \\
\hline Irony & 19 & 19 & 5 & 13 & 6 \\
\hline Joke & 2 & - & 2 & 2 & - \\
\hline Black humour & 1 & 1 & - & 1 & - \\
\hline Pun & 8 & 8 & 2 & 2 & 18 \\
\hline Anecdote & 18 & 9 & 3 & 3 & 4 \\
\hline Satire & 7 & 6 & 2 & - & 2 \\
\hline Caricature & 2 & 2 & 3 & 2 & \\
\hline
\end{tabular}

Table 2. Three Men on the Bummel

\begin{tabular}{|c|c|c|c|c|c|}
\hline $\begin{array}{c}\text { Humorous } \\
\text { devices }\end{array}$ & Superiority & $\begin{array}{c}\text { Communicative } \\
\text { (pragmatic) }\end{array}$ & Cultural & Linguistic & Situational \\
\hline Irony & 8 & 8 & 1 & 7 & 1 \\
\hline Joke & 11 & 6 & 3 & 10 & 1 \\
\hline Pun & 2 & 2 & 2 & 2 & 12 \\
\hline Anecdote & 20 & 17 & 18 & 14 & 4 \\
\hline Satire & 22 & 22 & - & - & 2 \\
\hline Caricature & 2 & 2 & 3 & \\
\hline
\end{tabular}


Table 3. Three Men in a Boat. Humour Equivalence at 5 levels

\begin{tabular}{|c|c|c|c|c|c|c|c|c|c|c|}
\hline \multicolumn{11}{|c|}{ Explicit Message } \\
\hline 1.communicative equivalence & \multicolumn{5}{|c|}{ Message Direct conveyance } & \multicolumn{5}{|c|}{ Message Indirect conveyance } \\
\hline & Translator 1 & Translator 2 & Translator 3 & Translator 4 & Translator 5 & Translator 1 & Translator 2 & Translator 3 & Translator 4 & Dece \\
\hline Comic superiority & 22 & 22 & 22 & 22 & 22 & - & - & - & - & - \\
\hline Comic suspense & 14 & 14 & 14 & 14 & 14 & - & - & - & - & - \\
\hline Comic surprise & 21 & 21 & 21 & 20 & 18 & 1 & 1 & 1 & 2 & 4 \\
\hline \multicolumn{11}{|c|}{ Implicit Message } \\
\hline Comic superiority & 35 & 35 & 35 & 35 & 35 & - & - & - & - & - \\
\hline Comic suspense & 24 & 26 & 25 & 25 & 26 & 4 & 2 & 3 & 3 & 2 \\
\hline Comic surprise & 29 & 31 & 30 & 31 & 33 & 6 & 4 & 5 & 4 & 2 \\
\hline \multicolumn{11}{|l|}{$\begin{array}{c}\text { 2.Equivalence at the } \\
\text { situational level }\end{array}$} \\
\hline Irony & & & & & & 19 & 19 & 19 & 19 & 19 \\
\hline Joke & 2 & 2 & 2 & 2 & 2 & & & & & \\
\hline Black humour & 1 & 1 & 1 & 1 & 1 & & & & & \\
\hline Pun & & & & & & 8 & 8 & 8 & 7 & 8 \\
\hline Anecdote & 18 & 18 & 18 & 18 & 18 & & & & & \\
\hline Satire & 7 & 7 & 7 & 7 & 7 & & & & & \\
\hline Caricature & & & & & & 2 & 2 & 2 & 2 & 2 \\
\hline \multicolumn{11}{|l|}{$\begin{array}{c}\text { 3.Equivalence at the level of } \\
\text { expression }\end{array}$} \\
\hline Irony & & & & & & 19 & 19 & 19 & 19 & 19 \\
\hline Caricature & & & & & & 2 & 2 & 2 & 2 & 2 \\
\hline Pun & & & & & & 8 & 8 & 7 & 8 & 8 \\
\hline \multicolumn{11}{|l|}{$\begin{array}{l}\text { 4.Equivalence at the } \\
\text { syntactical level }\end{array}$} \\
\hline Irony & & & & & & 11 & 10 & 8 & 6 & 15 \\
\hline Joke & 2 & 1 & - & - & 2 & & & & & \\
\hline Black humour & - & - & - & - & 1 & & & & & \\
\hline Pun & & & & & & 8 & 8 & 7 & 8 & 8 \\
\hline Anecdote & - & - & - & - & - & & & & & \\
\hline Caricature & & & & & & - & - & - & - & - \\
\hline \multicolumn{11}{|l|}{$\begin{array}{c}\text { 5.Equivalence at the level of } \\
\text { language signs }\end{array}$} \\
\hline Irony & & & & & & - & - & - & - & 2 \\
\hline Joke & - & - & - & - & & & & & & \\
\hline Black Humour & - & - & - & - & & & & & & \\
\hline Pun & & & & & & 8 & 8 & 7 & 8 & 8 \\
\hline Anecdote & - & - & - & - & & & & & & \\
\hline Caricature & & & & & & - & - & - & - & - \\
\hline
\end{tabular}


Table 4. Three Men on the Bummel. Humour Equivalence at the 5 levels

\begin{tabular}{|c|c|c|c|c|c|c|}
\hline \multicolumn{7}{|c|}{ Explicit Message } \\
\hline \multirow[t]{2}{*}{ 1.Equivalence at communicative level } & \multicolumn{3}{|c|}{ Message Direct conveyance } & \multicolumn{3}{|c|}{ Message indirect conveyance } \\
\hline & Translator 1 & Translator 2 & Translator 3 & Translator 1 & Translator 2 & Translator 3 \\
\hline Comic superiority & 33 & 33 & 33 & - & - & - \\
\hline Comic suspense & 26 & 26 & 27 & 2 & 2 & 1 \\
\hline Comic surprise & 31 & 31 & 31 & - & - & - \\
\hline \multicolumn{7}{|c|}{ Implicit Message } \\
\hline Comic superiority & 31 & 31 & 31 & - & - & - \\
\hline Comic suspense & 27 & 27 & 27 & - & - & - \\
\hline Comic surprise & 30 & 29 & 31 & 2 & 3 & 1 \\
\hline \multicolumn{7}{|l|}{ 2.Equivalence at situational level } \\
\hline Irony & & & & 8 & 8 & 8 \\
\hline Joke & 11 & 11 & 11 & & & \\
\hline Pun & & & & 2 & 2 & 2 \\
\hline Anecdote & 20 & 20 & 20 & & & \\
\hline Satire & 22 & 22 & 22 & & & \\
\hline Caricature & & & & 2 & 2 & 2 \\
\hline \multicolumn{7}{|l|}{$\begin{array}{c}\text { 3.Equivalence at the level of expression } \\
\text { pragmatic implicature }\end{array}$} \\
\hline Irony & & & & 8 & 8 & 8 \\
\hline Caricature & & & & 2 & 2 & 2 \\
\hline Pun & 2 & 2 & 2 & & & \\
\hline $\begin{array}{l}\text { 4.Equivalence at the level of syntactic unit } \\
\text { meaning }\end{array}$ & & & & 5 & 5 & 8 \\
\hline Irony & 7 & 8 & 10 & & & \\
\hline Joke & 6 & 7 & 10 & & & \\
\hline Pun & & & & 2 & 2 & 2 \\
\hline Anecdote & - & - & - & & & \\
\hline Satire & - & - & - & & & \\
\hline Caricature & & . & & - & - & - \\
\hline \multicolumn{7}{|l|}{$\begin{array}{l}\text { 5.Equivalence at the level of syntactic unit } \\
\text { meaning }\end{array}$} \\
\hline Irony & & & & 1 & 2 & 6 \\
\hline Joke & - & - & 2 & & & \\
\hline Pun & & & & 1 & 1 & 1 \\
\hline Anecdote & - & - & - & & & \\
\hline Satire & - & - & - & & & \\
\hline Caricature & & & & 1 & 1 & 1 \\
\hline
\end{tabular}

\section{Findings}

The results illustrated above illustrate the humorous devices diversity, ascertain and document the superiority and incongruity aspects that build the corpus of the present analysis. Throughout this research, it becomes clear that the humorous devices, which simultaneously combine superiority and incongruity are mostly ironic, anecdotal and satirical; what is more, incongruity is possible either at the linguistic, situational and cultural levels, the former having more priority. Still communicative incongruity gains prominence in both novels and acts as implying negative superiority which is present in all the selected humorous devices. Thus, the results obtained in Three men in a Boat humour analysis show that the novel is rich in irony and anecdotes whereas Three Men on the Bummel abounds in satire and anecdotes. Both novels tend to deride human weaknesses, social vice and are culture bound focusing on 
British, German ethnic, social, and gender peculiarities by means of caricature, satire, irony, etc.

Given the essential aspect of communicative incongruity and superiority within the analyzed humorous devices, table 3 reveals the implicit messages predominance being directly conveyed in the target language over the explicit messages conveyed either directly or indirectly. Consequently, the translators mentioned below did not convey comic superiority and comic suspense indirectly. As for equivalence at the situational level, it has been achieved by all the translators in all the types of humour devices which cannot be noted at the levels of expression excepting puns and irony. The equivalence at the level of syntactic unit meaning and at the level of language signs is impossible in most of the cases because of the large number of units.

\section{Conclusions}

One of the oldest human activities, translation is a complex and multifaceted process that does not refer merely to transferring words and meanings from one language into another. While translating a literary text, different cultures, mindsets, attitudes, cognitive and emotional states are encountered, consequently making the translators' work really challenging. As far as the question of translation equivalence is concerned, it is noteworthy that it is relative and very specific to different humour types. In the case of narrative humour superiority (social aspect) and incongruity (cognitive aspect) translation, the concept of equivalence was reduced to its communicative, situational, expressive/pragmatic/syntactic and language signs levels of directly or indirectly conveying comic superiority, suspense and surprise within explicit and implicit messages. Despite its complex and indefinite nature, equivalence still can be traced when referring to message, situation and intention conveyance due to the translators' remarkable skill.

\section{REFERENCES}

[1] Aristotle. Poetics. Butcher SH., translator. $3^{\text {rd }}$ ed. New York: the Macmillan Company, 1902.131p.

[2] Plato. (2002) The Republic. Anonymous translator. 484p, Online, available from http://www.idph.net

[3] T. Hobbes, (2013) Leviatah. White E., Widger D. translators. Online available fromhttp://www.gutenberg.org/files/3207/3 207-h/3207-h.htm\#link2H_4_0019

[4] J. Vandaele Humor Mechanisms in Film Comedy: Incongruity and Superiority. Poetics Today. 2002 February; 23, 221-242.

[5] Plato. (2002) The Republic. anonymous translator. 484p, Online, available from http://www.idph.net

[6] Aristotle. Poetics. Butcher SH., translator. $3^{\text {rd }}$ ed. New York: the Macmillan Company, 1902. 131p.

[7] R. Descartes (2012) Passions of the Soul. Benett J., translator. p.19. Online available from http://www.earlymoderntexts.co $\mathrm{m} / \mathrm{pdfs} /$ descartes1649.pdf

[8] Vandaele J. Each Time We Laugh Translated Humour in Screen Comedy. Translated Humour. 1999 p.241, 237-272

[9] N.E. Zalta. Sandford Encyclopedia of Philosophy. 2012 May; 2. Online available from http://plato.stanford.edu/entri es/hum

[10] A. Bain On the Study of Character, Including an Estimate on Phrenology. London: Savil and Edwards, Printers, Cados Street, Covet Garden, 1861. 345 p. Online available from https://books.google.md/books?id=xLhcAAAAcAAJ\&pg=P A292\&hl $=$ en $\# \mathrm{v}=$ onepage \&q $\& \mathrm{f}=$ false

[11] D.H. Monro Theories of Humor. Writing and Reading Across the Curriculum. 3rd ed. Laurence Behrens and Leonard J. Rosen, eds. Glenview, IL: Scott, Foresman and Company, 1988. 349-55. Online available fromhttps://www.msu.edu/ j dowell/monro.html

[12] N.E. Zalta. Sandford Encyclopedia of Philosophy. 2012 May; 2. Online available from http://plato.stanford.edu/entries/hu $\mathrm{m}$

[13] D.H. Monro Theories of Humor. Writing and Reading Across the Curriculum. 3rd ed. Laurence Behrens and Leonard J. Rosen, eds. Glenview, IL: Scott, Foresman and Company, 1988. 349-55. Online available fromhttps://www.msu.edu/ j dowell/monro.html

[14] G. Ritchie Variants of Incongruity Resolution. Journal of Literary Theory. 2009. Vol. 3 No. 2, 313-332, p. 322

[15] Vandaele J. Each Time We Laugh Translated Humour in Screen Comedy. Translated Humour. 1999 p.241, 237-272

[16] J. Vandaele, Humor Mechanisms in Film Comedy: Incongruity and Superiority. Poetics Today. 2002 23:2, p. 221-242.

[17] J. Vandaele Narrative Humour(II): Exit Perspective. Poetics Today. 2012. 33:1, Oslo: Duke University Press, 59-126

[18] J. Vandaele Narrative Humour(II): Exit Perspective. Poetics Today. 2012. 33:1, Oslo: Duke University Press, 59-126

[19] Vandaele J. Each Time We Laugh Translated Humour in Screen Comedy. Translated Humour. 1999 p.241, 237-272

[20] Ю.В. Зангирова Понятие эквивалентности перевода и ее типы. [The Concept of Equivalence and its Types]. 2010 Online available fromhttp://study-english.info/equivalence.p $\mathrm{hp}$

[21] Л. С. Бархударов (1975) Язык и перевод.[Language and Translation] Москва: Издательство Международные отношения, $238 \mathrm{p}$.

[22] V. Leonardi Equivalence in Translation: Between Myth and Reality. Translation Journal. 2000. Vol. 4, No. 4. Online available from $\mathrm{http}: / /$ translationjournal.net/journal/14equiv.h tm

[23] Комиссаров ВН. Эквивалентность перевода при передаче функционально-ситуативного содержания оригинала. [Translation Equivalence in Target TextFunctional-Situation 
al Content Conveyance] 2010 Online available from http://study-english.info/equivalence.php

[24] E.A. Nida, Taber, Ch R. The Theory and Practice of Translation. Leiden: Pulished for the United Bible Societies by E. J.Brill, 1982. 229 p.

[25] J. Catford A Linguistic Theory of Translation. London: Oxford University Press, 1965. 106 p.

[26] P. Newmark. A Textbook of Translation. New York: Prentice Hall 1988. 311 p.

[27] M. Baker In Other Words.London: Routlege Tyler and Francis Group, 1992. 317p.

[28] J. House Translation Quality Assessment: A Model Revisited. Tubingen: Gunter Narr Verlag 1997. 209p.

[29] Комиссаров ВН. Эквивалентность перевода при передаче функционально-ситуативного содержания оригинала. [Translation Equivalence in Target Text Functional-Situation al Content Conveyance] 2010 Online available from http://study-english.info/equivalence.php

[30] В. С. Виноградов Проблема эквивалентности и тип переводимого текста. Введение в переводоведение. [The Problem of Equivalence and the Type of Translated Text. Introduction to Translation Studies] Online available from http://study-english.info/equivalence.php

[31] Комиссаров ВН. Эквивалентность перевода при передаче функционально-ситуативного содержания оригинала. [Translation Equivalence in Target Text Functional-Situation al Content Conveyance] 2010 Online available from http://study-english.info/equivalence.php

[32] J. K. Jerome. Three Men in a Boat (to say nothing of the dog).London: Penguin Books 1889. 185 p.

[33] J. K. Jerome. Three Men on the Bummel. London: The Project Gutenberg Edition 1901. 314 p.

[34] J. K. Jerome. Trei într-o Barcă (fără a mai socoti și câinele). Levițchi L., translator. București: Editura Adevărul Holding 1957. $197 \mathrm{p}$.

[35] J. K. Jerome. Trei într-o Barcă (fără a mai pune la socoteală și câinele). Corduneanu B., translator. Chișinău: Editura Cartea Moldovenească 1959. 289p.

[36] J. K. Jerome. Trei într-o Barcă (fără a mai pune la socoteală și câinele). Bătrânu N., translator București: Editura Litera Internațional $1975.217 \mathrm{p}$.

[37] J. K. Jerome. Trei într-o Barcă (fără a mai pune la socoteală și câinele). by Decei L., translator. București: Grupul Editorial Corint 2006. 287p.

[38] J. K. Jerome. Trei într-o Barcă (fără a mai socoti și câinele). Nițescu, M., translator. București: Editura Univers 2009. $205 \mathrm{p}$.

[39] J. K. Jerome K. J. Trei pe Două Biciclete. Zarojanu T C., translator. București: Editura Octopodium 1994. 199p.

[40] J. K. Jerome K. J. Trei pe Două Biciclete. Decei L., translator. București: Grupul Editorial Corint 2006. 299p.

[41] J. K. Jerome K. J. Trei pe Două Biciclete. Duțescu D., translator. București: Editura Adevărul Holding. 2009. 197 p. 